\title{
Editorial Paper ARSITEKTUR DIGITAL SEBUAH KEPASTIAN
}

\author{
L.M.F. Purwanto \\ Editor in Chief, Journal of Digital Architecture \\ Program Studi Doktor Arsitektur, Konsentrasi Arsitektur Digital, Fakultas Arsitektur dan Desain, Universitas Katolik \\ Soegijapranata
}

DOI: $10.24167 /$ joda.v1i1.3698

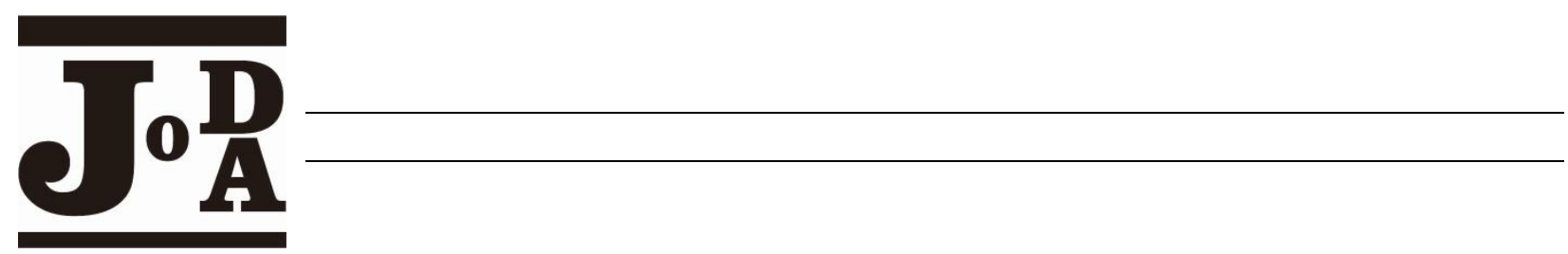

Dalam edisi perdana JoDA, Journal of Digital Architecture ini membahas tentang berbagai kajian tentang arsitektur digital. Dari masa ke masa, perkembangan arsitektur mengalami banyak perubahan dan perkembangan. Di awali dengan adanya komputer yang menggantikan alat gambar arsitek dengan kehadiran CAD. Kehadiran computer ini memudahkan dalam menggambar dan mulai memasuki era digital yang dapat menekan penggunaan kertas dalam penyajian gambar setelah komputer mulai terhubung dengan internet [1]. Setelah itu, beberapa software pendukung mulai berkembang dan membantu arsitek untuk mempermudah dalam pekerjaannya. Oleh sebab itu, arsitektur digital haruslah mempengaruhi pemikiran desain, metode desain, dan teori spasial [2]. Arsitektur digital dikembangkan untuk dapat digunakan dalam membantu proses berpikir desain dengan bantuan internet dan berbasis web yang nantinya akan membentuk sebuah teori baru. Jika metode desain, pola pikir, dan teori spasial semuanya diubah oleh arsitektur digital, maka di kemudian hari akan lebih dari sekadar teori.

Penggunaan teknologi menjadi berkembang pesat sejak segala sesuatu mulai terhubung dan tak terpisahkan dari internet. Perangkat lunak dan perangkat keras mulai saling melengkapi dan mempermudah dalam desain arsitektur [3]. Software tidak lagi hanya berkutat pada aspek fisika bangunan, tapi berkembang dalam segala aspek kajian arsitektur. Bahkan perangkat keras yang ditunjang dengan perangkat lunak yang mudah dioperasionalkan, tidak semata berupa komputer tetapi merambah ke gadget yang lebih mudah digunakan. Virtual reality dan Augmented Reality sebagai wacana kekinian yang sangat mudah digunakan dan dapat membantu interaksi desain dengan klien secara real time.

Memasuki dunia arsitektur digital menjadikan ilmu arsitektur terasa hidup dan mengasyikkan untuk dipelajari. Dunia seakan menjadi tempat selancar dan tanpa batas untuk dikembangkan dengan tatanan arsitektur yang lebih manusiawi dan ramah lingkungan. Dengan demikian arsitektur digital dapat didefinisikan sebagai sebuah revolusi [4]. Saat ini manusia dapat menunggu untuk melihat perubahan sosial budaya yang drastis, yang akan muncul di era digital. Tidak mudah untuk memprediksi masa depan arsitektur digital, meskipun saat ini sudah berkembang dengan kecepatan penuh. Terdapat gap antara pendidikan arsitektur, budaya masyarakat, dan arsitektur digital [5].

Pendidikan arsitektur harus berupaya mengikuti perubahan teknologi digital yang begitu cepat. Pendidikan arsitektur tradisional yang masih bertumpu pada teori filosofis, sosial, historis dan psikologis harus cepat tanggap dengan evolusi digital yang berjalan secara cepat ini. Masih banyak orang yang khawatir dengan penggunaan komputer yang berlebihan. Namun, mereka lupa bahwa teknologi baru selalu melahirkan budaya baru, seperti banyak catatan sejarah terkait perubahan dan dampak teknologi dalam budaya manusia. 
Pada awal tahun 1973, Bruno Zevi mendefinisikan transisi era digital saat ini, yang bukan semata dalam masa pertumbuhan [6]. Dalam beberapa dekade terakhir, arsitektur sebenarnya telah berkembang pesat seiring dengan inovasi teknologi, sehingga telah mampu mengatasi paradigma konstruksi konvensional, sehingga menghasilkan hubungan baru antara arsitektur dan manusia. Kehadiran robot dan printer 3D, mengubah cara arsitek mendesain sampai pada merealisasikannya dalam pembangunan bangunannya. Arsitektur memperoleh perluasan sosiologis dari perangkat teknologi dengan bentuk ekspresi baru berkat immaterialitas dari dunia maya.

Kini dengan kehadiran Arsitektur Digital, Arsitektur menjadi alat komunikatif global, sebuah ikon yang mentransmisikan pesan yang dapat membentuk cara memandang dan berpikir dalam agregasi elemen dalam aliran yang berkelanjutan dan tanpa urutan tertentu. Selamat memasuki era Arsitektur Digital.

\section{Pustaka}

[1] A. Andia, "Reconstructing the Effects of Computers on Practice and Education during the Past Three Decades", Journal of Architectural Education, 56, 2, pp. 7-13, 2002

[2] Yu-Tung Liu, "The Philosophy of Digital Architecture": The FEIDAD Award Architettura, 2001

[3] K. Sanders, "The Digital Architect: A Common-Sense Guide to Using Computer Technology in Design Practice", 1st edition, New Jersey, Wiley, 1995

[4] A. Goodhouse, "When Is the Digital in Architecture?", London,_Sternberg Press, 2017

[5] N. Spiller, "Digital Architecture Now", London, Thames \& Hudson, 2009

[6] B. Zevi, "Architecture As Space”, Revised edition, Boston, Da Capo Press, 1993 